\title{
The role of personality and role engagement in work-family balance
}

\author{
Johanna Rantanen ${ }^{1 *}$, Ulla Kinnunen ${ }^{2}$ and Lea Pulkkinen ${ }^{1}$ \\ ${ }^{1}$ University of Jyväskylä, Finland \\ ${ }^{2}$ University of Tampere, Finland
}

\begin{abstract}
The relations between personality, role engagement, and a four-dimensional typology of work-family balance (WFB) were examined within a community-based sample $(n=213)$ derived from the Jyväskylä Longitudinal Study of Personality and Social Development (JYLS). The typology was formed based on both work-family conflict (WFC) and enrichment (WFE) experiences. The profiles of personality and role engagement differentiated the four WFB types - Beneficial, Harmful, Active, and Passive types. The Beneficial type (low WFC, high WFE; 48.4\%) was characterized by low neuroticism, high agreeableness and high conscientiousness. The opposite was observed for the Harmful type (high WFC, low WFE; $8.9 \%$ ), which was also characterized by low family investment. In turn, high extraversion and high work and family investment characterized the Active type (high WFC, high WFE; 16.4\%), whereas low extraversion and openness to experience as well as low work investment characterized the Passive type (low WFC, low WFE; 26.3\%). Thus, rather than just being a unidimensional construct ranging from balance to imbalance, it is confirmed that WFB can also be seen as manifesting itself in multiple types, which are linked to meaningful differences in personality traits and role engagement.
\end{abstract}

Keywords: family work balance, role engagement, family relations, personality

\section{Vloga osebnostnih lastnosti in vključenosti v različne vloge pri ravnotežju med delom in družino}

\author{
Johanna Rantanen ${ }^{1}$, Ulla Kinnunen ${ }^{2}$ in Lea Pulkkinen ${ }^{1}$ \\ ${ }^{1}$ Universza v Jyväskyli, Finska \\ ${ }^{2}$ Univerza v Tamperi, Finska
}

Povzetek: Prek vzorca udeležencev $(n=213)$ iz vzdolžne študije Jyväskylä Longitudinal Study of Personality and Social Development (JYLS) smo proučevali povezave med osebnostjo, vključenostjo v različne vloge in štiri-dimenzionalno tipologijo ravnotežja med delom in družino. Tipologija je bila zasnovna na osnovi izkušenj konflikta in obogatitve med delom in družino. Štirje tipi (tj. ugodno ravnotežje, škodljivo ravnotežje, aktivno ravnotežje in pasivno ravnotežje) so se razlikovali tako v osebnostih lastnostih kot v vključenosti v različne vloge. Za osebe z ugodnim ravnotežjem (nizek konflikt, visoka obogatitev; 48,4 \%) je bila značilna višja čustvena stabilnost, višja sprejemljivost in višja vestnost. Ravno obrano je bilo mogoče opaziti pri osebah s škodljivim ravnotežjem (visok konflikt, nizka obogatitev; 8,9 \%), za katerega pa je bila dodatno značilna nižja vključenost v družinsko življenje. Visoka ekstravertnost in visoka vključenost v delovno vlogo ter v družinsko življenje so bile značilne za osebe z aktivnim ravnotežjem (visok konflikt, visoka obogatitev; 16.4 \%). Po drugi strani pa so bile nižja ekstravertnost in odprtost za izkušnje ter hkrati nižja vključenost v delo značilne za pasivno ravnotežje (nizek konflikt, nizka obogatitev; 26,3 \%). Na podlagi rezultatov lahko zaključimo, da ravnotežje med delom in družino ni enodimenzionalni konstrukt, temveč se kaže prek različnih tipov ravnotežja, za katere so značilne pomembne razlike v osebnostnih lastnostih in vključenosti v različne življenjske vloge.

Ključne besede: odnos med družino in delom, konflikti vlog, odnosi v družini, osebnost

\footnotetext{
"Naslov/Address: Johanna Rantanen, Department of Psychology, P.O. Box 35, 40014 University of Jyväskylä, Finland. e-mail: k.johanna.rantanen@jyu.fi
}

Članek je licenciran pod pogoji Creative Commons Attribution 4.0 International licence. (CC-BY licenca). The article is licensed under a Creative Commons Attribution 4.0 International License (CC-BY license). 
Psychological views on the concept of work-family balance (WFB) have been classified into overall appraisals and the components approach (Grzywacz \& Carlson, 2007). Overall appraisals refer to individuals' general assessment of their entire life situation (e.g., "All in all, how successful do you feel in balancing your work and personal/family life?"; Clarke, Koch, \& Hill, 2004), whereas the components approach views WFB as constituting different measurable dimensions such as time, engagement, and satisfaction balance (Greenhaus, Collins, \& Shaw, 2003) or work-family conflict and enrichment (Frone, 2003). Recently, however, a typological approach to WFB has been suggested in which WFB is not seen as a single state or continuum ranging from balance to imbalance (cf. Frone, 2003; Greenhaus et al., 2003) but instead as manifesting itself in four types of WFB that are hypothesized to differ from each other in psychological functioning and role engagement (Rantanen, Kinnunen, Mauno, \& Tillemann, 2011; Rantanen, Kinnunen, Mauno, \& Tement, 2013). The subjective well-being differences between the four types of WFB are well studied (Demerouti \& Geurts, 2004; Grzywacz, Butler, \& Almeida, 2008; Mauno, Rantanen, \& Kinnunen, 2011; Rantanen et al., 2013) but the other hypothesis concerning role engagement as well as the personality differences between these types are not. Hence, the aim of the present study was to examine how the types of WFB differ from each other with regard to the Big Five personality traits as well as work and family role engagement.

\section{Typological approach to WFB}

Work-family interface refers to a situation where work and family domains interact, that is affect each other. Depending on the quality of this interaction, work-family interface can be either negative or positive (Geurts \& Demerouti, 2003). Accordingly, the construct of workfamily conflict (WFC) refers to the negative interface between work and family domains, whereas work-family enrichment (WFE) refers to the positive interface. More specifically, WFC refers to the perceived difficulty of fulfilling simultaneous and/or conflicting work and family demands due to insufficiency of time- and energyrelated individual resources (Greenhaus \& Beutell, 1985). In contrast, WFE refers to the perceived ease of fulfilling work and family demands due to beneficial skills, support, and resources received from participating in the other (work or family) domain (Frone, 2003; Greenhaus \& Powell, 2006).

In work-family interface research, WFC and WFE have typically been seen as experiences that are opposite and exclude each other, as for example in Frone's (2003) conceptualization of WFB comprised of high WFE and low WFC. On the contrary, in the typological approach to WFB adopted in the present study, the different types of WFB are expected to exist as a combination of WFC and WFE experiences (Demerouti \& Geurts, 2004; Grzywacz et al., 2008; Rantanen et al., 2011). The main tenet of the typological approach to WFB is that it is possible to experience both WFC and WFE simultaneously with varying levels. Hence, WFC and WFE do not operate in isolation, but instead they work together to define the total experience and nature of WFB (Rantanen et al., 2011). For example, long weekly working hours may prevent an individual from participating in family duties, thus giving rise to an experience of WFC. Nevertheless, at the same time, the long weekly working hours may provide the desired financial security for the family, thereby eliciting an experience of WFE.

Accordingly, there are four WFB types hypothesized in this approach, which are as follows: the Beneficial type consisting of high WFE and low WFC (also named the Positive interaction or Balanced type), the Harmful type consisting of high WFC and low WFE (also named the Negative interaction or Imbalanced type), the Active type consisting of high WFC and high WFE (also named the Negative and positive interaction or Blurred type), and the Passive type consisting of low WFC and low WFE (also named the No interaction or Segmented type) (Demerouti \& Geurts, 2004; Grzywacz et al., 2008; Rantanen et al., 2011). Based on the demands and resources approach to work-family interface (Bakker \& Geurts, 2004; Voydanoff, 2005), it is assumed that beneficial WFB results from the low demands and high resources attached to work and family roles, harmful WFB from high demands and low resources, active WFB from both high demands and resources, and passive WFB from both low demands and resources (Rantanen et al., 2011).

Hence, the gains received from the participation in work and family roles exceed the demands of these roles for individuals experiencing beneficial WFB, whereas the opposite happens for individuals experiencing harmful WFB. As a result, in accordance with the theories of role conflict (Greenhaus \& Beutell, 1985; Kahn, Wolfe, Quinn, Snoek, \& Rosenthal, 1964) and role enhancement (Barnett \& Hyde, 2001; Marks, 1977; Sieber, 1974), beneficial WFB is expected to facilitate psychological functioning and well-being, whereas harmful WFB threatens it. This is seen as the main differentiating factor between these two types of WFB (Rantanen et al., 2011).

In active WFB, due to high work- and family-related resources coupled with high demands both WFE and WFC are experienced simultaneously (cf. the earlier example concerning long working hours) and thus, high WFC does not necessarily impair one's psychological functioning and well-being if high WFE buffers it. In passive WFB, on the other hand, because low work-family resources are coupled with low demands neither WFE nor WFC are experienced, and thus a strong threat to psychological functioning and well-being is not present. The main differentiating factor between these types of WFB is therefore assumed to be something other than psychological well-being (Rantanen et al., 2011), namely role engagement based on the theory of role balance by Marks and MacDermid (1996). Marks and MacDermid (1996) state that role balance reflects a behavioural and 
cognitive-affective pattern of acting and feeling across roles with either high or low dedication. Thus, active WFB may reflect an individual orientation to be highly engaged in work and family roles by choice (i.e., will to succeed and achieve happiness in both life spheres) but in the presence of high demands from these roles, this high dual investment may be both rewarding and overloading. Passive WFB, in turn, may reflect low engagement in work and family roles. Therefore, conflicting role demands are perhaps avoided, but rewards that enhance role performances are also not gained (Rantanen et al., 2011).

\section{The Big Five personality traits, WFC and WFE}

Individual differences cover a broad spectrum of factors that describe the way in which the behaviour and performance of human beings differ from each other (Hogan, Harkness, \& Lubinski, 2000). In the occupational psychology literature, it is common that many narrow personality traits such as Type A behaviour, locus of control, self-efficacy, or negative affectivity are studied one by one in different studies (Mäkikangas, Feldt, Kinnunen, \& Mauno, 2013). Instead, in the present study, the five-factor model of personality (FFM), often entitled the Big Five, was chosen as the framework for investigating the personality differences between the WFB types. The FFM represents a working consensus on the descriptive structure of personality traits (Caspi \& Shiner, 2006; Roberts \& Wood, 2006) as it covers and organizes the lower level and narrower personality traits into highest level individual differences, that is, into Big Five personality traits: neuroticism (vs. emotional stability), extraversion, openness to experience (or intellect), agreeableness, and conscientiousness (e.g., Digman, 1997; McCrae \& Costa, 2003).

The distinctive feature of neuroticism is the temperamental tendency to experience negative affect and to view the surrounding world as psychosocially distressing and threatening (Caspi, Roberts, \& Shiner, 2005; McCrae \& Costa, 2003). Extraversion contains both temperamental and interpersonal dimensions: individuals high in this trait are sensitive to positive emotions and potential rewards, and they are assertive, active, and vigorous in their actions and social relationships (Caspi et al., 2005; McCrae \& Costa, 2003). Agreeableness and conscientiousness are regarded as instrumental personality traits (McCrae \& Costa, 1991). Individuals high in agreeableness are characterized as altruistic, compliant, and straightforward, which promotes interpersonal bonding and social success, and the characteristics of conscientious individuals - orderliness, dutifulness, self-discipline, and achievement-striving - promote effectiveness in daily tasks and success in work (Caspi et al., 2005; McCrae \& Costa, 1991, 2003).
Openness to experience (referred to as openness hereafter) differs to some extent from the other Big Five personality traits and it is the least understood of these traits (Caspi et al., 2005). Openness is characterized by a deep scope of emotional and intellectual awareness and by a need to enlarge and examine experience, which is shown in the imaginative, aesthetic, unconventional, and curious nature of open individuals (McCrae \& Costa, 1997, 2003). Openness seems to be "a double-edged sword" that intensifies the magnitude of both the positive and negative experiences that open individuals encounter (McCrae \& Costa, 1991, 1997).

Following Bolger and Zuckerman's (1995) framework of studying personality in the stress process, Rantanen, Pulkkinen, and Kinnunen (2005) have presented a Personality-Conflict-Distress model in which the Big Five personality traits are considered as antecedent of WFC in addition to work and family demands. Later, Grant and Langan-Fox (2007) presented a similar model concerning general occupational stressor-strain relationships. In both of these models, the Big Five personality traits are also regarded as possible moderators of the WFC/occupational stressor-psychological strain relationship, the perspective of which, however, is not the focus of the present study.

According to Rantanen et al. (2005), neuroticism is assumed to be a risk factor predisposing one to the experience of WFC, and the other Big Five traits are assumed to be resource factors preventing one from the experience of WFC. The rationale behind this is that individuals high in neuroticism are prone to viewing demanding work-family circumstances as an obstacle that cannot be overcome or resolved, but which overwhelms them and causes stress, that is, high WFC. In contrast, individuals high in extraversion, agreeableness, and conscientiousness are likely to see a similar situation as a challenge in which they can respond due to their personal (i.e., activity and vigour related to extraversion; effectiveness, organisational skills, and orderliness related to conscientiousness) and interpersonal (i.e., social networks and support related to extraversion and agreeableness) resources. Hence, these individuals are less likely to experience WFC because of these personalityrelated resources. Individuals high in openness in turn are not assumed to differ from others in WFC (Rantanen et al., 2005). A recent and extensive meta-analysis $(N=$ $8,723)$ confirms all these assumptions: WFC is related most strongly to neuroticism (a positive association) and also to some extent to extraversion, agreeableness, and conscientiousness (a negative association), but not to openness (Michel, Clark, \& Jaramillo, 2011).

Concerning WFE, it has also been proposed within the Resource-Gain-Development perspective that personal characteristics such as positive affectivity can act as antecedents promoting work-family facilitation (Wayne, Grzywacz, Carlson, \& Kacmar, 2007) and the meta-analysis conducted by Michel, Clark et al. (2011) supports this proposition. In particular, WFE is related 
most strongly to extraversion and openness (a positive association), and also to some extent to agreeableness and conscientiousness (a positive association), but not to neuroticism.

In sum, it seems that personality traits reflecting psychosocial maturity, that is, emotional stability (the opposite of neuroticism), agreeableness, and conscientiousness are related to low WFC through the fact that these traits promote socialization and success in adulthood roles (career, job, marriage) (Caspi et al., 2005; Digman, 1997; Hogan \& Roberts, 2004; Lodi-Smith \& Roberts, 2007). Extraversion and openness in turn reflect agency, self-fulfilment, and personal growth (Digman, 1997). These two traits are related to high WFE presumably through the fact that agency, sensitivity to rewards, and positive emotions as well as search for personal growth may foster the recognition, acquisition, and transfer of resources between work and family domains, which then enrich each other. The question that remains unanswered is: how are the Big Five traits related to the types of WFB, which represent qualitatively different combinations of WFC and WFE experiences?

\section{Role engagement, WFC and WFE}

In the present study, role engagement was approached from two perspectives: 1) actual time invested in work and family roles, and 2) personal life investment directed towards work and family roles. The amount of time that an individual spends on work and family roles captures one external behavioural pattern of acting across roles with either high or low engagement assumed to be the main differentiating factor between the Active and Passive types (Rantanen et al., 2011). Personal life investment, defined as actions and thoughts directed towards central life domains (Staudinger \& Fleeson, 1996), in turn captures the internal cognitive-affective pattern of acting and feeling across the work and family roles. Hence, these two perspectives on role engagement complement each other.

A meta-analysis by Michel, Kotrba, Mitchelson, Clark, and Baltes (2011) clearly shows that both work and family time demands are positively related to WFC but there is not yet similar, extensive analysis available for WFE. It seems, however, that at least weekly working hours are unrelated to WFE (Kinnunen, Feldt, Geurts, \& Pulkkinen, 2006; Wayne, Musisca, \& Fleeson, 2004). The meta-analysis by Michel, Kotrba et al. (2011) also shows that psychological job involvement is positively related to WFC, although not as strongly as work time demands. In regard to WFE, the findings show that it is positively related to job involvement and effort, but negatively related to family involvement and effort (Aryee, Srinivas, \& Tan, 2005; Wayne et al., 2004).

Taken together these findings support the notion that both external (time investment) and internal (personal life investment) role engagement might differ between the types of WFB. However, it seems possible that the time investment across work and family roles might show a different profile between these types compared to the personal life investment, because work time demands have been linked only to WFC, whereas psychological job involvement has been linked to both WFC and WFE.

\section{The present study}

Although there is knowledge on how personality traits and work and family role engagement are related to WFC and WFE independently, the understanding is lacking how these antecedents are related to the total experience of WFB, that is to the types of WFB defined by the level and specific combination of WFC and WFE experiences.

Rantanen et al. (2011) have assumed that the main differentiating factor between beneficial and harmful WFB is psychological functioning, whereas between active and passive WFB it is role engagement. The Big Five personality traits can be organized further into two higherorder metatraits, namely the alpha factor comprising low neuroticism, highagreeablenessand conscientiousness, and the beta factor comprising high extraversion and openness (Digman, 1997). The alpha factor reflects psychosocial maturity, whereas the beta factor reflects personal growth and self-fulfilment (Caspi et al., 2005; Digman, 1997; Hogan \& Roberts, 2004). We suggest that conceptually the alpha factor reflecting psychosocial maturity shares a similarity with psychological functioning, because both emphasize mental and social well-being and capability. We also suggest that the beta factor reflecting personal growth and self-fulfilment shares a similarity with role engagement because both of these concepts emphasize active and dedicated orientation towards life.

Hence, we expected first, the Beneficial type to show the most, and the Harmful type the least personality traits related to psychosocial maturity, and second, the Active type to show the most, and the Passive type the least personality traits related to personal growth. Our specific hypotheses were:

Hypothesis 1: Neuroticism, agreeableness, and conscientiousness differentiate the Beneficial and Harmful types of WFB: the former shows lower neuroticism, higher agreeableness and higher conscientiousness than the latter.

Hypothesis 2: Extraversion and openness differentiate the Active and Passive types of WFB: the former shows higher extraversion and higher openness than the latter.

We used longitudinal data to investigate whether the types of WFB were related as hypothesized above to concurrent personality as well as to the personality assessments already made nine years earlier. This longterm relationship was expected based on the strong rank-order stability observed in personality traits across adulthood (Rantanen, Metsäpelto, Feldt, Pulkkinen, \& Kokko, 2007; Roberts \& DelVecchio, 2000). 
Finally, we studied role engagement from the perspectives of actual time invested in work and family roles, and personal life investment directed towards work and family roles. Our third hypothesis was:

Hypothesis 3: Time and personal life investment differentiates the Active and Passive types of WFB: the former shows higher time and personal life investment in work and family roles than the latter.

\section{Method}

\section{Participants and procedure}

The data for the present study were gathered in 1992 and 2001 as part of the ongoing Finnish Jyväskylä Longitudinal Study of Personality and Social Development (JYLS) started in 1968 (Pulkkinen, 2006). The original sample consisted of all 369 pupils (196 boys and 173 girls born mostly in 1959) in 12 urban and suburban, randomly selected second-grade school classes in the City of Jyväskylä in Central Finland. The sample in adulthood at age 42 in 2001 has proven to be representative of the age cohort born in 1959 in Finland regarding marital status, number of children, and employment status (Pulkkinen, 2006). Those participants who at age 42 were employed and had a family (spouse/partner and/or children living at home) were included in the present study. These criteria yielded 213 participants (106 men, 107 women). At age 33 in 1992, the data about personality traits were collected through a mailed questionnaire, and at age 42 a mailed life situation questionnaire was sent to the participants followed by psychological interviews with self-report scales and personality questionnaires.

\section{Measures}

Work-family balance. WFC and WFE were measured at age 42 with a 14 -item composite work-family interface scale with items derived from Frone, Russell, and Cooper (1992); Netemeyer, Boles, and McMurrian (1996); and Geurts et al. (2005). The construct validity of this composite scale has been reported by Kinnunen et al. (2006). It measures WFC with eight items, which cover conflicts arising from work to family (e.g., "How often does your job or career interfere with your responsibilities at home, such as cooking, shopping, child care, yard work, or repairs?") and from family to work (e.g., "How often does it happen that family related strain interferes with your ability to perform job-related duties?"). WFE was measured with six items, which cover enrichment from work to family (e.g., "How often does it happen that you come home cheerfully after a successful day at work, positively affecting the atmosphere at home?") and from family to work (e.g., "How often does it happen that you manage your time at work more efficiently because at home you have to do that as well?"). The response scale ranged from 1 (never) to 5 (very often), and the Cronbach's alpha was .83 for WFC, and .72 for WFE.

Personality traits. Neuroticism, extraversion, openness, agreeableness, and conscientiousness were measured at ages 33 and 42 with a 60-item shortened version of the Big Five personality inventory (Pulver, Allik, Pulkkinen, \& Hämäläinen, 1995), which is an authorized Finnish adaptation of Costa and McCrae's (1985) NEO Personality Inventory (NEO-PI). In the short version, eight items are substituted for items in the American original, due to differences in culture and society. Each personality trait - neuroticism (e.g., "When I'm under a great deal of stress, sometimes I feel like I'm going to pieces"), extraversion (e.g., "I am a cheerful, high-spirited person", "I am a very active person"), openness (e.g., "I am intrigued by the patterns I find in art and nature", "I have a lot of intellectual curiosity"), agreeableness (e.g., "I would rather cooperate with others than compete with them"), and conscientiousness (e.g., "I have a clear set of goals and work towards them in an orderly fashion") - was measured with 12 items with a response scale from 1 (strongly disagree) to 5 (strongly agree). The internal consistency of these traits has been proven to be satisfactory in JYLS (the Cronbach's alphas ranging between .74 and .86; for more detail see Rantanen et al., 2007).

Role engagement. Time invested in work and family roles were obtained at age 42 with four questions: "How many hours per week do you work, on average, including paid work, overtime hours, and work done at home?", "How many hours per week, on average, do you use in caring for your children and your home, such as cooking, cleaning, home repairs, etc.?", "Do you think that you have enough time of your own that you can use in the way you like?", and "Do you feel that you must continuously give up your time for others at home or at work?" Participants reported the number of hours for the first two questions and evaluated the latter two questions using a scale from 1 (not at all) to 4 (a lot). Personal life investments at age 42 , that is, the degree of action and thought towards work and family, were both assessed with one item (e.g., "Tasks related to your profession or work. How much do you think about it or do something about it?") with a response scale from 1 (currently think/do nothing) to 5 (currently think/do very much) (Staudinger \& Fleeson, 1996).

\section{Data analyses}

The WFB types were formed by dichotomizing the averaged sum scores of the WFC and WFE variables (scale from 1 to 5) into two groups using 2.5 as the cut-off point, and then the dichotomized WFC and WFE variables were cross-tabulated to obtain Beneficial, Harmful, Active, and Passive types. This cut-off point was chosen because WFC is generally reported according to a proportion of the population experiencing conflict at least "sometimes," which is a scale midpoint (Bellavia \& Frone, 2005). This way the WFB types are anchored in the response scale 
instead of, for example, mean or median splits of the variable mean scores, which are sample specific and hinder the comparison of results between different samples.

The differences between the WFB types in the study variables were examined through a general linear model profile analysis with covariates (i.e., application of MANCOVA). Each group of variables (personality traits at ages 33 and 42, time investment at age 42, and personal life investment at age 42) were set as dependent variables, one variable group at a time and within one time-point at a time (at age 33 or 42). The WFB type variable was set as a between subject factor along with gender $(1=$ woman, $2=$ man $)$, occupational level $(1=$ blue-collar worker, $2=$ lower white-collar worker, 3 = upper white-collar worker), marital status $(1=$ married or cohabiting, $2=$ living without partner), and number of children (range 0-5) as covariates. These demographic features were considered as covariates because they are salient factors in relation to work-family interface (Bellavia \& Frone, 2005). The pairwise comparisons in each variable between the four WFB types were based on the parameter estimates of the profile analysis model.

The Shapiro-Wilk tests of normality showed that of the personality trait variables all except neuroticism at ages 33 and 42 and agreeableness at age 33 were normally distributed ( $p>.05$ for all), whereas time and personal life investment variables comprised of one question/item at age 42 were not $(p<.05$ for all). Ocular inspection showed that there were some outliers in these variables not meeting the assumption of normality, and therefore, the variables were normalized for each WFB type separately to avoid producing unreliability in the profile analysis results. After that the data were imputed using the Expectation Maximization (EM) algorithm including all study variables, as there were missing data both because some participants had chosen not to participate in data collection at age 33, or did not answer all self-report questions at age 42 . The percentages of missing values in the study variables (Table 1) were generally between $0 \%$ (e.g., weekly working hours at age 42) and 7\% (personality traits at age 42). The largest missing data related to age 33, when $20 \%$ of the participants in the present study had not returned the mailed Big Five personality inventory. The missing value analysis showed that the missing data in the study variables were completely random and did not indicate selectivity $\left[\chi^{2}(567)=617.18, p=.071\right]$, according to Little's MCAR test (Little, 1988).

However, to ensure the representativeness of the sample, profile analyses were performed with imputed data from all participants. The obtained results were compared to analyses performed with original data that excluded participants with missing values in each analysis. After imputation, the study variables were standardized due to differences in response scales in order to produce a comparable representation of the WFB type profiles within and between each variable group.

\section{Results}

\section{Descriptive analyses}

The correlation between WFC $(M=2.12, S D=0.60)$ and WFE $(M=2.84, S D=0.60)$ scales was very small and not significant $(r=.04, p=.612)$, indicating that these experiences are independent of each other and that the typology of WFC and WFE experiences is plausible. When these two scales were dichotomized using the 2.5 cut-off point, $75 \%$ of the participants $(n=159)$ were classified as not experiencing WFC and $25 \%(n=54)$ as experiencing it at least sometimes. Accordingly, $35 \%$ of the participants $(n=75)$ were classified as not experiencing WFE and 65\% $(n=138)$ as experiencing this at least sometimes. The four types of WFB were formed based on these classifications and half of the participants $(48.4 \%, n=103)$ belonged to the Beneficial type, $8.9 \%(n=19)$ belonged to the Harmful type, $16.4 \%(n=35)$ belonged to the Active type, and $26.3 \%(n=56)$ belonged to the Passive type.

The descriptive statistics for covariates and study variables (before normalizing and imputation) within each WFB type and for the whole sample are given in Table 1. The examination of covariates showed, first, that in comparison to the sample distribution there were more women than men in the Beneficial type, whereas there were more men than women in the Harmful type $\left[\chi^{2}(3)=10.36, p\right.$ $=.016]$. Second, there were more blue-collar workers and fewer upper white-collar workers in the Passive type than in the other types, and there were more upper white-collar workers in the Harmful type than in other types $\left[\chi^{2}(6)=\right.$ $18.29, p=.006]$. Third, participants in the Active balance type had more children than participants in the Passive and Beneficial types $[F(3)=4.72, p=.003]$.

\section{Profile analyses}

Regarding personality traits, the Beneficial and Harmful types differed from each other the most (Table 2; Figure 1). The participants in the former type reported less neuroticism $(\beta=-1.09, p=.000, \eta=.10)$ and openness $(\beta=$ $-0.50, p=.036, \eta=.03)$, and more extraversion $(\beta=0.59, p$ $=.042, \eta=.02)$, agreeableness $(\beta=0.72, p=.004, \eta=.04)$, and conscientiousness $(\beta=0.66, p=.009, \eta=.03)$ than the participants in the latter type, for whom the profile was the opposite. Concerning neuroticism, agreeableness, and conscientiousness these results fully support our Hypothesis 1. The Active type participants differed from other types in neuroticism and extraversion, reporting more neuroticism than the Beneficial type participants $(\beta$ $=0.76, p=.000, \eta=.08)$ and more extraversion than the Harmful $(\beta=0.56, p=.042, \eta=.02)$ and Passive $(\beta=0.52$, $p=.017, \eta=.03)$ type participants. This finding that the Active type reported more extraversion than the Passive type partially supports our Hypothesis 2 . In addition, the Passive type participants differed from other types in all personality traits. In neuroticism, they were higher than 
Table 1. Descriptive statistics for work-family balance types: demographic covariates and study variables

\begin{tabular}{|c|c|c|c|c|c|}
\hline & $\begin{array}{r}\text { Beneficial type } \\
\% \text { or } M(S D)\end{array}$ & $\begin{array}{l}\text { Harmful type } \\
\% \text { or } M(S D)\end{array}$ & $\begin{array}{r}\text { Active type } \\
\% \text { or } M(S D)\end{array}$ & $\begin{array}{l}\text { Passive type } \\
\% \text { or } M(S D)\end{array}$ & $\begin{array}{r}\text { Whole sample } \\
\% \text { or } M(S D)\end{array}$ \\
\hline \multicolumn{6}{|l|}{ Covariates } \\
\hline $\operatorname{Gender}^{1}(n=213)$ & $60 \% / 40 \%$ & $26 \% / 74 \%$ & $49 \% / 51 \%$ & $41 \% / 59 \%$ & $50 \% / 50 \%$ \\
\hline Occupational level $^{2}(n=213)$ & $24 \% / 47 \% / 29 \%$ & $26 \% / 21 \% / 53 \%$ & $28 \% / 29 \% / 43 \%$ & $43 \% / 43 \% / 14 \%$ & $30 \% / 40 \% / 30 \%$ \\
\hline Marital status $(n=213)$ & $83 \% / 17 \%$ & $80 \% / 21 \%$ & $89 \% / 11 \%$ & $82 / 18 \%$ & $84 \% / 16 \%$ \\
\hline Number of children $(n=213)$ & $1.55(0.99)$ & $1.63(1.26)$ & $2.17(1.04)$ & $1.30(1.21)$ & $1.60(1.11)$ \\
\hline \multicolumn{6}{|l|}{ Study variables } \\
\hline Neuroticism, age $42(n=199)$ & $2.13(0.52)$ & $2.69(0.79)$ & $2.53(0.64)$ & $2.47(0.67)$ & $2.33(0.63)$ \\
\hline Neuroticism, age $33(n=170)$ & $2.52(0.63)$ & $2.92(0.72)$ & $2.70(0.57)$ & $2.74(0.65)$ & $2.64(0.65)$ \\
\hline Extraversion, age $42(n=199)$ & $3.45(0.53)$ & $3.18(0.51)$ & $3.50(0.50)$ & $3.10(0.57)$ & $3.34(0.56)$ \\
\hline Extraversion, age $33(n=170)$ & $3.28(0.53)$ & $2.99(0.45)$ & $3.28(0.59)$ & $3.15(0.50)$ & $3.21(0.53)$ \\
\hline Openness, age $42(n=199)$ & $3.36(0.58)$ & $3.57(0.64)$ & $3.36(0.51)$ & $3.15(0.65)$ & $3.32(0.60)$ \\
\hline Openness, age $33(n=170)$ & $3.22(0.49)$ & $3.58(0.54)$ & $3.32(0.61)$ & $3.14(0.60)$ & $3.25(0.55)$ \\
\hline Agreeableness, age $42(n=199)$ & $3.74(0.52)$ & $3.37(0.47)$ & $3.57(0.57)$ & $3.59(0.49)$ & $3.64(0.52)$ \\
\hline Agreeableness, age $33(n=170)$ & $3.64(0.50)$ & $3.27(0.52)$ & $3.49(0.67)$ & $3.48(0.44)$ & $3.54(0.53)$ \\
\hline Conscientiousness, age $42(n=199)$ & $3.84(0.48)$ & $3.46(0.47)$ & $3.65(0.61)$ & $3.57(0.53)$ & $3.71(0.53)$ \\
\hline Conscientiousness, age $33(n=170)$ & $3.65(0.51)$ & $3.27(0.53)$ & $3.69(0.48)$ & $3.44(0.54)$ & $3.56(0.53)$ \\
\hline $\begin{array}{l}\text { Weekly working hours, age } 42 \\
(n=213)\end{array}$ & $40.11(8.84)$ & $47.27(11.15)$ & $48.67(20.39)$ & $40.63(7.85)$ & $42.29(11.95)$ \\
\hline $\begin{array}{l}\text { Weekly domestic work hours, age } 42 \\
(n=203)\end{array}$ & $13.79(9.13)$ & $13.22(12.51)$ & $18.38(15.74)$ & $10.45(7.37)$ & $13.52(10.63)$ \\
\hline $\begin{array}{l}\text { Sufficiency of own time, age } 42 \\
(n=210)\end{array}$ & $3.12(0.76)$ & $2.06(0.73)$ & $2.49(0.82)$ & $3.25(0.84)$ & $2.96(0.87)$ \\
\hline $\begin{array}{l}\text { Giving up time for others, age } 42 \\
(n=208)\end{array}$ & $1.72(0.99)$ & $1.89(1.13)$ & $2.50(1.19)$ & $1.85(1.04)$ & $1.90(1.08)$ \\
\hline Work investment, age $42(n=211)$ & $4.02(0.86)$ & $4.26(0.73)$ & $4.26(0.70)$ & $3.75(0.91)$ & $4.01(0.85)$ \\
\hline Family investment, age $42(n=208)$ & $4.36(0.63)$ & $3.79(0.86)$ & $4.46(0.70)$ & $4.21(0.63)$ & $4.28(0.68)$ \\
\hline
\end{tabular}

${ }^{1}$ women/men

${ }^{2}$ blue-collar workers/lower white-collar workers/upper white-collar workers

${ }^{3}$ married or cohabitating/living without partner

the Beneficial type participants $(\beta=0.46, p=.003, \eta=$ $.04)$, but lower than the Harmful type participants $(\beta=$ $-0.63, p=.011, \eta=.03)$. In extraversion $(\beta=-0.54, p=.001$, $\eta=.04)$ and conscientiousness $(\beta=-0.45, p=.007, \eta=$ $.04)$, they were lower than the Beneficial type participants. Compared to the Harmful type participants, they were lower in openness $(\beta=-0.70, p=.006, \eta=.04)$, but higher in agreeableness $(\beta=0.56, p=.035, \eta=.02)$.

Of the 14 significant differences between the WFB types in personality traits at age 42 , eight were also detected nine years earlier (Table 2). The most consistent were the differences between the Beneficial and Harmful types showing almost the same personality profiles at ages 33 and 42, and the profiles of the Active and Beneficial types also showed high resemblance between ages 33 and 42 (as can also be concluded from the relative order of means for each trait between types in Table 1). Already at age 33, the Beneficial type participants were lower in neuroticism $(\beta=-0.85, p=.000, \eta=.06)$ and openness $(\beta=-0.72, p=.003, \eta=.04)$, and higher in extraversion $(\beta=0.56, p=.028, \eta=.02)$, agreeableness $(\beta=0.60, p$ $=.014, \eta=.03)$ and conscientiousness $(\beta=0.77, p=.002$, $\eta=.05)$ than the Harmful type participants. The Active type participants differed from other types by reporting more neuroticism than the Beneficial type participants ( $\beta=0.51, p=.005, \eta=.04)$ and more conscientiousness than the Harmful type participants $(\beta=0.68, p=.017, \eta=$ $.03)$. Finally, the Passive type participants were lower than the Harmful type participants in neuroticism $(\beta=-0.57, p$ $=.022, \eta=.03)$ and openness $(\beta=-0.88, p=.001, \eta=.06)$.

In time investment across work and family roles, the Active type differed most from other types (Table 2; Figure 1). Participants in this type reported more weekly working hours $(\beta=0.71, p=.000, \eta=.07 ; \beta=$ 
Table 2. Results of profile analyses

\begin{tabular}{|c|c|c|}
\hline \multicolumn{3}{|l|}{ Profile } \\
\hline Personality traits & $\begin{array}{c}\text { Age } 42 \\
\text { Wilks' } \lambda=.75 \\
F(12,534.73)=5.17 \\
p=.000, \eta=.09\end{array}$ & $\begin{array}{c}\text { Age 33 } \\
\text { Wilks' } \lambda=.83, \\
F(12,534.73)=3.33, \\
p=.000, \eta=.06\end{array}$ \\
\hline Neuroticism & $1<2,3,4 ; 4<2$ & $1,4<2 ; 1<3$ \\
\hline Extraversion & $1,3>2,4$ & $1>2$ \\
\hline Openness & $1,4<2$ & $1,4<2$ \\
\hline Agreeableness & $1,4^{\mathrm{a}}>2$ & $1>2$ \\
\hline Conscientiousness & $1>2,4$ & $1,3>2$ \\
\hline Time investment & \multicolumn{2}{|c|}{$\begin{array}{c}\text { Age } 42 \\
\text { Wilks' } \lambda=.78, F(9,494.20)=6.00, p=.000, \eta=.08\end{array}$} \\
\hline Weekly working hours & \multicolumn{2}{|c|}{$1,4<2^{a}, 3$} \\
\hline Weekly domestic work hours & \multicolumn{2}{|c|}{$1,4<3$} \\
\hline Sufficiency of own time & \multicolumn{2}{|c|}{$2<1,3^{\text {a }}, 4 ; 3<1,4$} \\
\hline Giving up time for others & \multicolumn{2}{|c|}{$1,4<3$} \\
\hline Personal life investment & \multicolumn{2}{|c|}{ Age 42} \\
\hline Work investment & \multicolumn{2}{|c|}{$3>4$} \\
\hline Family investment & \multicolumn{2}{|c|}{$1,3,4>2$} \\
\hline
\end{tabular}

Note. 1 = Beneficial type, 2 = Harmful type, 3 = Active type, 4 = Passive type. Work-family balance type differences at the level of $p<.05$ in single variables are based on parameter estimates of the profile analysis (i.e., MANCOVA) models.

$F$-values are reported based on imputed data $(n=213)$ and Box's tests show equality of covariance matrices $(p>.05)$ between the types in personality traits and personal life investment analyses, but not in time investment analysis $(p<.05)$. Levene's tests show equality of error variances between the types in all other variables $(p>.05)$ except in weekly working and domestic work hours $(p<.05)$.

${ }^{a}$ Significant difference found only in imputed data.

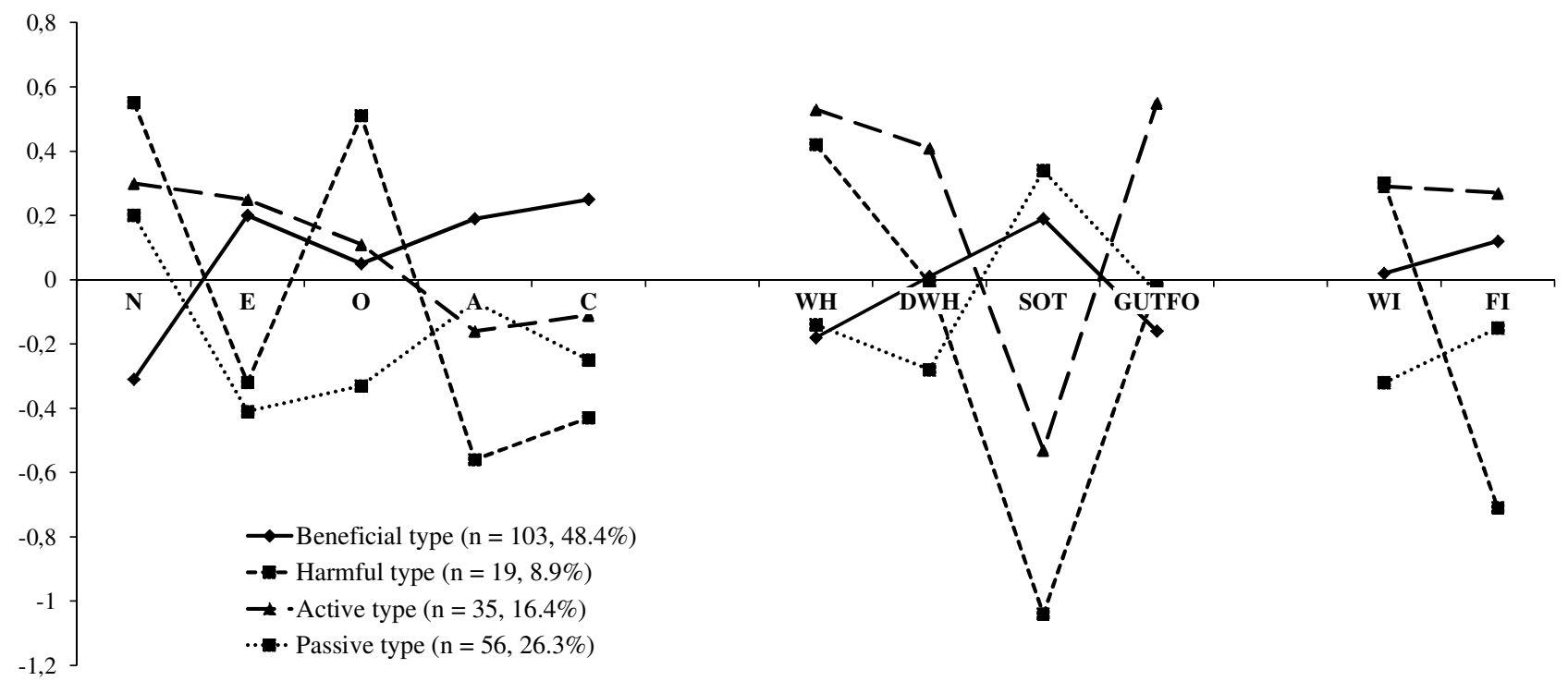

Figure 1. Profiles of personality, time investment, and personal life investment for each work-family balance type at age 42 based on standardized scores in MANCOVA models with imputed data $(n=213) . \mathrm{N}=\mathrm{Neuroticism}, \mathrm{E}=$ Extraversion, $\mathrm{O}=$ Openness, $\mathrm{A}=$ Agreeableness, $\mathrm{C}=$ Conscientiousness, $\mathrm{WH}=$ Working hours, $\mathrm{DWH}=\mathrm{Domestic}$ working hours, $\mathrm{SOT}=$ Sufficiency of own time, GUTFO $=$ Giving up time for others, WI $=$ Work investment, FI $=$ Family investment 
$0.79, p=.000, \eta=.07)$, domestic work hours $(\beta=0.36, p$ $=.040, \eta=.02 ; \beta=0.46, p=.020, \eta=.03)$, giving up time for others $(\beta=0.67, p=.001, \eta=.05 ; \beta=0.48, p=.029$, $\eta=.02)$, and less time for just themselves $(\beta=0.63, p$ $=.000, \eta=.06 ; \beta=0.68, p=.001, \eta=.05)$ than participants in the Beneficial and Passive types. These differences found between the Active and Passive types support our Hypothesis 3. In addition, the Harmful type participants reported more weekly working hours $(\beta=0.47, p=.049$, $\eta=.02 ; \beta=0.55, p=.031, \eta=.02)$ and less time for just themselves $(\beta=-1.23, p=.000, \eta=.13 ; \beta=-1.28, p=.000$, $\eta=.12$ ) than the Beneficial and Passive type participants. The Harmful type participants also had less time for just themselves $(\beta=-0.60, p=.021, \eta=.03)$ than the Active type participants.

In personal life investments, the Active type participants showed more work investment $(\beta=0.51, p=.021, \eta=$ .03 ) than the Passive type participants (Table 2; Figure 1) supporting our Hypothesis 3. In addition, the Harmful type differed most from other types in relation to personal life investment towards family. The participants in this type invested least in their family, differing significantly from the Beneficial $(\beta=-0.83, p=.001, \eta=.05)$, Active $(\beta=$ $-0.91, p=.001, \eta=.05)$ and Passive $(\beta=-0.64, p=.016$, $\eta=.03$ ) type participants. Finally, as shown in Table 2 , the imputed and non-imputed data produced highly similar results.

\section{Discussion}

The present study lends support to the still less familiar typological approach to WFB by showing that WFC and WFE are independent constructs that can be experienced in multiple combinations - Beneficial, Harmful, Active, and Passive types - which differ meaningfully from each other. While the subjective well-being differences between these types are known (Demerouti \& Geurts, 2004; Grzywacz et al., 2008; Mauno et al., 2011; Rantanen et al., 2013), the present study produced new knowledge about the differences between these types in personality and role engagement.

\section{Prevalence of WFB}

The prevalence rates of the WFB types found in the present study closely resemble those found in the cluster analysis of Demerouti and Geurts (2004), who also had an occupationally heterogeneous European (Dutch) sample like ours. This gives support for the plausibility of these types and the typological approach to WFB. In comparison, roughly $48 \%$ of the participants in the present study belonged to the Beneficial type, whereas $41 \%$ of them belonged to the corresponding Positive home-work interaction and Positive work-home interaction clusters found in the study by Demerouti and Geurts (2004). Accordingly, 9\% were in the Harmful type versus $10 \%$ in the Negative interaction cluster, $16 \%$ in the Active type versus $17 \%$ in the Positive and negative interaction cluster, and $26 \%$ in the Passive type versus $32 \%$ in the No interaction cluster.

On the other hand, in the US study by Grzywacz et al. (2008) only $9 \%$ of the participants belonged to the most favourable Balanced type that corresponds with the present Beneficial type (48\%). This huge difference may reflect a true cultural effect-Finland is a more work-family friendly country than the USA - or a methodological difference between the studies, or a combination of both. Grzywacz et al. (2008) used a median split to form the four types of WFB using WFC and WFE variables, whereas we used a scale midpoint, anchored in the response scale, which enhances the comparison of results between different samples.

\section{Personality traits and WFB}

Based on the present results, the notion that psychosocial maturity, that is, low neuroticism and high agreeableness and conscientiousness, is likely to promote good socialization and success in adulthood roles (Caspi et al., 2005; Digman, 1997; Hogan \& Roberts, 2004) can be extended to also concern achieving an ideal balance between work and family life. Low neuroticism was related to a specific combination of high WFE and low WFC, that is, the Beneficial type in the present study, whereas in previous studies examining the independent associations between the Big Five personality traits and WFC or WFE, neuroticism has been related to WFC only (a positive relation; meta-analysis by Michel, Clark et al., 2011). High agreeableness and conscientiousness were also related to this type, which is in accord with studies showing a negative association between WFC, and a positive association between WFE and these two traits (Michel, Clark et al., 2011).

The present results also showed that high agency in terms of extraversion was related to the Beneficial and Active types of WFB reflecting a positive and active workfamily interface. This finding supports the notion that personal growth may promote an individual's adjustment (Digman, 1997), and the view that extraversion mostly defines the experience of WFE (Michel, Clark et al., 2011) rather than both WFE and WFC (Grzywacz \& Marks, 2000). The present results concerning openness, the other constituent of personal growth (Digman, 1997), showed, in turn, that if an individual's investments in work are high, then high openness coupled with a personality showing low psychosocial maturity may not promote adjustment, but instead lead to the detrimental balance between work and family roles seen in the Harmful type. This finding is opposite to cumulative findings showing that openness is related only to WFE (a positive relation; Michel, Clark et al., 2011). Due to this contradiction in results, the role of openness in relation to WFB should be examined more thoroughly before further conclusions can be drawn. Gender, for example, may alter the relation between openness and WFC: earlier findings using the same JYLS data at age 36 showed that openness was 
positively related to WFC in men, but not in women (Rantanen et al., 2005). In the present study, there were also more men than women in the Harmful type showing high openness.

In the present study, the personality differences between the WFB types were also tested longitudinally, in contrast to earlier studies that have mostly relied on crosssectional data (Michel, Clark et al., 2011). This testing showed that, although the WFB type allocation was based on work-family interface experiences at age 42 , the profiles of personality traits at age 33 showed high resemblance with the corresponding profiles at age 42 . This similarity of personality trait profiles within the WFB types across nine years, from age 33 to 42 , is a consistent finding with respect to the high rank-order stability of personality traits observed in adulthood (Rantanen et al., 2007; Roberts \& DelVecchio, 2000). It also supports the notion that personality traits can be regarded as preceding risk and resource factors for work-family interface experiences as proposed in work-family interface models (Rantanen et al., 2005; Wayne et al., 2007). Furthermore, the rankorder stability of WFC has been shown to be moderately high in adulthood across six years (Rantanen, Kinnunen, Feldt, \& Pulkkinen, 2008), and tentative findings across three years show that WFE has the same stable tendency (Rantanen, Mauno, Mäkikangas, \& Kinnunen, 2012). Hence, the rank-order stability of WFC and WFE might also explain the similarity in the personality profiles within the WFB types across time.

\section{Role engagement and WFB}

We studied time invested in work and family roles as external and behavioural, and personal life investment directed towards work and family life as internal and cognitive-affective indicators of role engagement. We found that high weekly working hours and insufficiency of own time were related to the Harmful and Active types experiencing WFC. Although this result should be considered with some caution due to the high and differing variance found in working hours in the Active type in comparison to the other types (Tables 1 and 2), it corresponds well with the notion of time as a limited resource, one of the basic forms of WFC (Greenhaus \& Beutell, 1985), as well as with previous research (metaanalysis by Michel, Kotrba et al., 2011). Furthermore, the finding that work investment was highest in the Active type is in line with previous findings (Aryee et al., 2005; Michel, Kotrba et al., 2011; Wayne et al., 2004) and confirmed the hypothesis of high role engagement being characteristic for the Active type.

Family investment, in turn, was lowest within the Harmful type (high WFC and low WFE). In previous research, both high WFC and high WFE has either been related to low family involvement and effort (Aryee et al., 2005; Wayne et al., 2004) or a relation between WFC and family involvement has not been detected (Michel, Kotrba et al., 2011). This contradiction between earlier and present results may reflect the primary nature of the typological approach to WFB: when WFC and WFE experiences are considered in combination, the result is something more than can be expected based on the effects of isolated factors, that is, WFC or WFE alone. However, the present result is in line with the finding that individuals who show high engagement towards their work and family roles and favour their family over their work have a higher quality of life than those favouring their work over their family (Greenhaus et al., 2003). Accordingly, those whose investment was very low in their family but high in their work belonged to the Harmful type known to report low subjective well-being (Demerouti \& Geurts, 2004; Grzywacz et al., 2008; Rantanen et al., 2011).

\section{Limitations and future directions}

The present findings should be considered in the light of the following limitations. A methodological restriction associated with the present study is that WFB types were based on the dichotomization of the WFC and WFE measures. However, more advanced statistical methods such as latent profile analysis, recently used by Mauno et al. (2011) and Rantanen et al. (2013), failed to function with our relatively small data. These recent studies also emphasize the importance of taking the direction of effect in WFC and WFE experiences (i.e., conflict and enrichment can occur from work to family and from family to work) into account when investigating the types of WFB. In both of these studies, a type called Contradictory has emerged, which shows simultaneously harmful balance in work-tofamily and beneficial balance in family-to-work direction. With a bigger sample, this approach and latent profile analysis might also have produced this type in the present study. However, due to positive and sometimes also high correlations between work-to-family and family-to-work conflict as well as between work-to-family and familyto-work enrichment, WFC and WFE can be regarded as higher-order constructs comprising these sub-dimensions (Rantanen et al., 2011). Supporting this, a previous study with the JYLS sample at age 42 showed that the latent factor correlation between the sub-dimensions of WFC was .54 and for the sub-dimensions of WFE it was .87 (Kinnunen et al., 2006).

A larger sample would also have allowed us to study the interaction effects between the typology of WFB, gender, and occupational level. In the light of the present descriptive results showing that these factors were related to the allocation of WFB types, it would have been valuable to further examine this issue. The age-homogeneity of the present sample is yet another limitation of the study that affects the generalization of the results. Further studies are needed to investigate whether and how age affects the prevalence of the WFB types. For example, Demerouti and Geurts (2004) found that the postal employees in the Positive work-home interaction type were the oldest, and those in the Negative interaction and No interaction types were the youngest ones. 
It should also be noted that in the present study we adopted the traditional view that personality traits influence the way in which individuals view and respond to the developmental tasks they encounter (Caspi \& Shiner, 2006) such as finding balance between work and family lives in adulthood. But likewise, social roles such as being an employee, a spouse, or a parent and events experienced in these roles may foster personality change as argued within the neo-socioanalytic model of personality (Roberts \& Wood, 2006). Unfortunately, despite our longitudinal data, we were unable to investigate this latter view, because both WFC and WFE have been measured in the JYLS data at the first time at age 42 , whereas personality traits have been measured already at age 33 and then at age 42 . However, work and family roles are so central to many adults that it is plausible to think that the kind of balance - beneficial, harmful, active, or passive - one finds between these roles might also have an effect on one's personality. This is especially so if the kind of WFB one has contradicts one's deeper selfperceptions and expectations concerning managing these roles (Roberts \& Wood, 2006). This is a very interesting and recommendable avenue for future research.

Another avenue might be interviews and participatory research among individuals who show psychosocial maturity in terms of personality traits and have found beneficial WFB in their lives. This is because the present results suggest that promoting psychosocial maturity - low neuroticism, and high agreeableness and conscientiousness - might matter in terms of WFB. By interviewing and observing these individuals, it might be possible to grasp the successful daily practices that they use to manage their work and family roles as well as their ways of coping during those times when demands from these roles are in conflict. These good practices and ways of coping could then be taught through counselling and training to those having more difficulties in finding beneficial WFB. Hence, the primary aim is not to change personality, but to teach individuals more functional ways of action that - if successful in providing positive experiences, outcomes, and feedback - can later on also change these individuals' views on themselves, that is, their personality (Roberts \& Wood, 2006).

\section{Conclusion}

The four-dimensional typology of WFB examined here corresponds both with the overall appraisals and the components approach to WFB. As the four different types refer to individuals' overall experience of the quality of work-family interface in their lives, the typology fits the overall appraisal approach. It also suits the components approach to WFB, because the four types are based on the multidimensional measurement of work-family interface, as recommended by Grzywacz and Carlson (2007). The examination of personality traits is a unique contribution of the present study, since the role of personality has not been considered in any earlier approach to WFB. The present findings suggest that the personality traits describing psychosocial maturity are likely to be preceding factors for successful functioning in adulthood roles (e.g., Caspi et al., 2005; Hogan \& Roberts, 2004), such as achieving favourable balance between work and family lives.

Aknowledgements. This research was supported by grants from the Academy of Finland awarded to Johanna Rantanen (138369) and Lea Pulkkinen (127125).

\section{References}

Aryee, S., Srinivas, E. S., \& Tan, H. H. (2005). Rhythms of life: Antecedents and outcomes of work-family balance in employed parents. Journal of Applied Psychology, 90, 132-146.

Bakker, A. B., \& Geurts, S. A. E. (2004). Toward a dualprocess model of work-home interference. Work and Occupations, 31, 345-366.

Barnett, R. C., \& Hyde, J. S. (2001). Women, men, work, and family. American Psychologist, 56, 781-796.

Bellavia, G. M., \& Frone, M. R. (2005). Work-family conflict. In J. Barling, E. K. Kelloway, \& M. R. Frone (Eds.), Handbook of work stress (pp. 113-147). Thousand Oaks, California, USA: Sage.

Bolger, N., \& Zuckerman, A. (1995). A framework for studying personality in the stress process. Journal of Personality and Social Psychology, 69, 890-902.

Caspi, A., Roberts, B. W., \& Shiner, R. L. (2005). Personality development: Stability and change. Annual Review of Psychology, 56, 453-484.

Caspi, A., \& Shiner, R. L. (2006). Personality development. In W. Damon \& R. Lerner (Series Eds.), N. Eisenberg (Vol. Ed.), Handbook of child psychology, Social, emotional, and personality development (6th ed.) (pp. 300-365). New York, NY, USA: Wiley.

Clarke, M. C., Koch, L. C., \& Hill, E. J. (2004). The workfamily interface: Differentiating balance and fit. Family \& Consumer Sciences Research Journal, 33, 121-140.

Costa, P. T. Jr., \& McCrae, R. R. (1985). The NEO Personality Inventory manual. Odessa, FL, USA: Psychological Assessment Resources.

Demerouti, E., \& Geurts, S. (2004). Towards a typology of work-home interaction. Community, Work \& Family, 7, 285-309.

Digman, J. M. (1997). Higher-order factors of the Big Five. Journal of Personality and Social Psychology, 73, 1246-1256.

Frone, M. R. (2003). Work-family balance. In J. C. Quick, \& L. E. Tetrick (Eds.), Handbook of occupational health psychology (pp. 143-162). Washington, DC, USA: American Psychological Association.

Frone, M. R., Russell, M., \& Cooper, M. L. (1992). Antecedents and outcomes of work-family conflict: Testing a model of the work-family interface. Journal of Applied Psychology, 77, 65-78. 
Geurts, S., \& Demerouti, E. (2003). Work/non-work interface: A review of theories and findings. In M. J. Schabracq, J. A. M. Winnubst, \& C. L. Cooper (Eds.), The handbook of work and health psychology (pp. 279-312). Chichester: John Wiley \& Sons.

Geurts, S., Taris, T. W., Kompier, M. A., Dikkers, J. S., van Hooff, M. L., \& Kinnunen, U. (2005). Work-home interaction from a work psychological perspective: Development and validation of a new questionnaire, the SWING. Work \& Stress, 19, 319-339.

Grant, S., \& Langan-Fox, J. (2007). Personality and the occupational stressor-strain relationship: The role of Big Five. Journal of Occupational Health Psychology, 12, 20-33.

Greenhaus, J. H., \& Beutell, N. J. (1985). Sources and conflict between work and family roles. Academy of Management Review, 10, 76-88.

Greenhaus, J. H., Collins, K. M., \& Shaw, J. D. (2003). The relation between work-family balance and quality of life. Journal of Vocational Behavior, 63, 510-531.

Greenhaus, J. H., \& Powell, G. N. (2006). When work and family are allies: A theory of work-family enrichment. The Academy of Management Review, 31, 72-92.

Grzywacz, J. G., Butler, A. B., \& Almeida, D. M. (2008). Work, family, and health: Work-family balance as a protective factor against stresses of daily life. In A. Marcus-Newhall, D. F. Halpern \& S. J. Tan (Eds.), The Changing realities of work and family (pp. 194215). Oxford, United Kingdom: Wiley-Blackwell.

Grzywacz, J. G., \& Carlson, D. S. (2007). Conceptualizing work-family balance: Implications for practice and research. Advances in Developing Human Resources, 9, 455-471.

Grzywacz, J. G., \& Marks, N. F. (2000). Reconceptualizing the work-family interface: An ecological perspective on the correlates of positive and negative spillover between work and family. Journal of Occupational Health Psychology, 5, 111-126.

Hogan, R., Harkness, A. R., \& Lubinski, D. (2000). Personality and individual differences. In K. Pawlik, \& M. R. Rosenzweig (Eds.), International handbook of psychology (pp. 283-304). Thousand Oaks, CA, USA: Sage.

Hogan, R., \& Roberts, B. W. (2004). A socioanalytic model of maturity. Journal of Career Assessment, 12, 207-217.

Kahn, R. L., Wolfe, D. M., Quinn, R. P., Snoek, J. D., \& Rosenthal, R. A. (1964). Organizational stress: Studies in role conflict and ambiguity. Oxford, England: John Wiley.

Kinnunen, U., Feldt, T., Geurts, S., \& Pulkkinen, L. (2006). Types of work-family interface: Well-being correlates of negative and positive spillover between work and family. Scandinavian Journal of Psychology, 47, 149-162.

Little, R. J. (1988). A test of missing completely at random for multivariate data with missing values. Journal of the American Statistical Association, 83, 1198-1202.
Lodi-Smith, J., \& Roberts, B. W. (2007). Social investment and personality: A meta-analysis of the relationship of personality traits to investment in work, family, religion, and volunteerism. Personality and Social Psychology Review, 11, 1-19.

Mäkikangas, A., Feldt, T., Kinnunen, U., \& Mauno, S. (2013). Does personality matter? A review of individual differences in occupational well-being. In A.B.Bakker(Ed.), Advances in positiveorganizational psychology. (Vol. 1, pp. 107-143). Bingley, United Kingdom: Emerald.

Marks, S. R. (1977). Multiple roles and role strain: Some notes on human energy, time and commitment. American Sociological Review, 42, 921-936.

Marks, S. R., \& MacDermid, S. M. (1996). Multiple roles and the self: A theory of role balance. Journal of Marriage \& the Family, 58, 417-432.

Mauno, S., Rantanen, J., \& Kinnunen, U. (2011). Workfamily balance and its correlates among Finnish academic professionals: Profiling the experiences of work-family conflict and enrichment. In IBOP (Eds.), The future of knowledge-intensive service work: Theory and practice of managing human and organizational resources (pp. 319-341). Marburg, Germany: Metropolis.

McCrae, R. R., \& Costa, P. T. Jr. (1991). Adding Liebe und Arbeit: The full Five-Factor Model and wellbeing. Personality and Social Psychology Bulletin, 17, 227-232.

McCrae, R. R., \& Costa, P. T. Jr. (1997). Conceptions and correlates of openness to experience. In R. Hogan, J. A. Johnson, \& S. R. Briggs (Eds.), Handbook of personality psychology (pp. 825-847). San Diego, CA, USA: Academic Press.

McCrae, R. R., \& Costa, P. T. Jr. (2003). Personality in adulthood: A Five-Factor theory perspective (2nd ed.). New York: Guilford Press.

Michel, J., Clark, M., \& Jaramillo, D. (2011). The role of the Five Factor Model of personality in the perceptions of negative and positive forms of worknonwork spillover: A meta-analytic review. Journal of Vocational Behavior, 79, 191-203.

Michel, J., Kotrba, L., Mitchelson, J., Clark, M., \& Baltes, B. (2011). Antecedents of work-family conflict: A meta-analytic review. Journal of Organizational Behavior, 32, 689-725.

Netemeyer, R. G., Boles, J. S., \& McMurrian, R. (1996). Development and validation of work-family conflict and family-work conflict scales. Journal of Applied Psychology, 81, 400-410.

Pulkkinen, L. (2006). The Jyväskylä Longitudinal Study of personality and social development (JYLS). In L. Pulkkinen, J. Kaprio, \& R. J. Rose (Eds.), Socioemotional development and health from adolescence to adulthood (pp. 29-55). New York, NY, USA: Cambridge University Press.

Pulver, A., Allik, J., Pulkkinen, L., \& Hämäläinen, M. (1995). A Big Five personality inventory in two 
non-indo-european languages. European Journal of Personality, 9, 109-124.

Rantanen, J., Kinnunen, U., Feldt, T., \& Pulkkinen, L. (2008). Work-family conflict and psychological wellbeing: Stability and cross-lagged relations within one- and six-year follow-up. Journal of Vocational Behavior, 73, 37-51.

Rantanen, J., Kinnunen, U., Mauno, S. \& Tillemann, K. (2011). Introducing theoretical approaches to work-life balance and testing a new typology among professionals. In S. Kaiser, M. J. Ringlstetter, M. Pina e Cunha \& D. R. Eikhof (Eds.), Creating balance? International perspectives on the work-life integration of professionals (pp. 27-42). Berlin/Heidelberg, Germany: Springer.

Rantanen, J., Mauno, S., Kinnunen, U. \& Tement, S. (2013). Patterns of conflict and enrichment in workfamily balance: A three-dimensional typology. Work \& Stress, 27, 141-163.

Rantanen, J., Mauno, S., Mäkikangas, A., \& Kinnunen, U. (2012, April). Interplay between work-family conflict and enrichment: Three-wave study. Paper presented at the tenth Conference of the European Academy of Occupational Health Psychology, Zürich.

Rantanen, J., Metsäpelto, R-L., Feldt, T., Pulkkinen, L., \& Kokko, K. (2007). Long-term stability in the Big Five personality traits in adulthood. Scandinavian Journal of Psychology, 48, 511-518.

Rantanen, J., Pulkkinen, L., \& Kinnunen, U. (2005). The Big Five personality dimensions, work-family conflict, and psychological distress: A longitudinal view. Journal of Individual Differences, 26, 155-166.

Roberts, B. W., \& DelVecchio, W. F. (2000). The rankorder consistency of personality traits from childhood to old age: A quantitative review of longitudinal studies. Psychological Bulletin, 126, 3-25.

Roberts, B. W., \& Wood, D. (2006). Personality development in the context of the neo-socioanalytic model of personality. In D. K. Mroczek \& T. D. Little (Eds.), Handbook of personality development (pp. 11-39). Mahwah, NJ, USA: Lawrence Erlbaum.

Sieber, S. D. (1974). Toward a theory of role accumulation. American Sociological Review, 39, 567-578.

Staudinger, U. M., \& Fleeson, W. (1996). Self and personality in old and very old age: A sample case of resilience? Development and Psychopathology, 8, 867-885.

Voydanoff, P. (2005). Toward a conceptualization of perceived work-family fit and balance: A demands and resources approach. Journal of Marriage and Family, 67, 822-836.

Wayne, J. H., Grzywacz, J. G., Carlson, D. S., \& Kacmar, K. M. (2007). Work-family facilitation: A theoretical explanation and model of primary antecedents and consequences. Human Resource Management Review, 17, 63-76.
Wayne, J. H., Musisca, N., \& Fleeson, W. (2004). Considering the role of personality in the work-family experience: Relationships of the big five to workfamily conflict and facilitation. Journal of Vocational Behavior, 64, 108-130. 